\title{
Eating Behavior in a Sample of Overweight and Obese: A Cross Sectional Study
}

\section{Ahmed Salih Sahib'*, Tamara Sadeq Raheem¹, Maryam Shamal Saleh', Lina Saud khleel', Aya Mufeed Abdulhussein ${ }^{1}$, Shams Reyadh Sadiq ${ }^{1}$ and Faris Abdul Kareem Kazaal ${ }^{2}$}

\author{
${ }^{1}$ Department of Pharmacology, Al-Kindy College of Medicine, University of Bagdad, Baghdad, Iraq \\ ${ }^{2}$ Obesity Therapy and Research Unit, Al-Kindy College of Medicine, University of Bagdad, Baghdad, Iraq
}

*Corresponding author: Ahmed Salih Sahib, Head of Pharmacology Department, Al-Kindy College of Medicine, University of Baghdad, Baghdad, Iraq, Tel: +964-7901585579, E-mail: ahmedsalih73@yahoo.com

\begin{abstract}
Background: Obesity is becoming a public health problem worldwide especially in the recent years, thus; overweight and obesity are increasingly being observed among the population. The purpose of this study was to investigate the eating habits in a sample of overweight and obese Iraqi subjects who attend Al-Kindy obesity therapy and research unit.

Methods: A cross-sectional study was carried out on 111 subjects ( $34.2 \%$ male and $65.8 \%$ female), aged $39.6 \pm 12.24$ years, who were chosen randomly during February to May 2016. Subjects were asked to fill out a self-reported questionnaire that included questions on their eating, drinking and smoking habits. Statistical analyses were performed using SPSS (version 17.0) to determine overweight and obesity among subjects and to categorize eating habits.

Results: This study showed that the majority of the subjects $(44.1 \%)$ were of obese class 1 . The prevalence of obesity was more common among females compared to males. Eating habits of the subjects showed that the majority $(55.0 \%)$ reported taking three meals per day. We found that female subject rarely skip breakfast $(49.3 \%)$ compared to male subjects $(42.1 \%)$ in terms of breakfast intake. Vegetables and fruits intake was common among male $(65.8 \%)$ compared to female $(61.6 \%)$.
\end{abstract}

Conclusion: We found statistically significant positive association between specific eating behaviors, namely: number of meals per day, eating fatty food and fast food with obesity and overweight in a sample of Iraqi subjects.

\section{Keywords}

Obesity, Overweight, Eating behavior

\section{Introduction}

Obesity can be defined as a condition of abnormal or excess fat accumulation in adipose tissue, to the extent that health may be impaired. Body Mass Index (BMI), which is calculated as [(weight in $\mathrm{kg}$ ) / (height in $\mathrm{m})^{2}$ ], is considered to be the most useful populationlevel measure of obesity, and it is a simple index to classify underweight, overweight and obesity in adults. The WHO has classified overweight and obesity in adults based on various BMI cutoffs [1]. Obesity is becoming a public health problem worldwide especially in recent years. For instance, globally, there are more than 1 billion overweight adults, at least 300 million of whom are obese [1,2]. The prevalence of excess weight (overweight and obesity) among United Kingdom (UK) adults in 1996 was $59 \%$ in men and $49 \%$ in women while two-thirds of adults in the United States (US) in the year 2000 were overweight and $30.5 \%$ were obese [3]. In Iraq there is no national figure available, but one study carried out in Baghdad in 1997 showed that the prevalence of obesity was $23.16 \%$ in women aged 25 years old and above [4]. The reasons behind this "epidemic" could be attributed primarily to an energy imbalance and diet should be a major target for its prevention. Recently, there is evidence supporting the role of eating behaviors in the development of overweight [5-7]. Among the various eating behaviors, intake of high energydense foods is considered as a cause of weight gain, overweight and obesity, especially when large portion sizes are consumed regularly, a diet rich in fatty foods, snacking and eating quickly have shown to be associated with increased prevalence of obesity, the frequency of eating and the style of eating may also contribute to obesity [8]. Several studies have shown that sedentary lifestyles for example, prolonged television viewing, physical inactivity, and unhealthy eating habits during childhood was associated with an elevated risk of developing obesity $[9,10]$. Advances in technology and transportation have reduced the need for physical activity in daily life. There is a direct correlation between obesity and the method of transportation people choose. In the United States, people rely heavily on their cars. Countries that do not rely heavily on cars for everyday transportation have lower rates of obesity [11]. One environmental characteristic that has attracted a good deal of interest is stress. However, no simple relationship with eating behavior has emerged. In animal studies, stress has been shown to cause both hyperphagia (over- eating) and hypophagia (under-eating), with some evidence that milder stresses enhance food intake, while more severe stresses depress it. Human research has produced equally varied findings, although most people show a tendency to increase intake of sweet and fatty foods relatively more than protein under stress, which may be part of a coping response [12]. It was hypothesized that the elevated cortisol secretion, caused by stress, might disrupt the food intake regulation in humans and could result in a long-term increased energy intake and fat accumulation [13]. These findings have led to the hypothesis that the risks for obesity are not only genetic but are indeed amplified 
by an unhealthy lifestyle during childhood [14]. The secondary reasons are familial and genetic predisposition, psychological factors, diseases (hypothyroidism, Cushing syndrome) and drugs (steroids, tricyclic antidepressants, sulfonylureas, valproate and contraceptives) that may play a role in the etiology of obesity $[3,15]$. Obesity isn't just a cosmetic concern. It increases the risk of diseases and health related problems, such as heart disease, diabetes, high blood pressure, stroke, gall bladder disease, osteoarthritis, sleep apnea, some forms of cancer and infertility. Obesity is also associated with hyperlipidemia, pregnancy complications, hirsutism $[3,15]$. Obese children report a lower quality of life and demonstrate more negative self-perceptions, decreased selfworth, increased behavioral problems, and lower perceived cognitive ability [16]. Life expectancy can be shortened and all the associated co morbidities will increase the medical expenses [17], many of the strategies for successful weight loss and maintenance will help prevent obesity. Following a healthy lifestyle can help to prevent overweight and obesity and this can be done mainly by improving eating habits (cutting calories, making healthier choices, restricting certain foods) and increasing physical activity. Providing health education for the consumers in order to reduce portion sizes, which may help to limit opportunities for "passive overeating." The food and restaurant industries should be encouraged to take responsible actions by reducing portion sizes, especially of high- energy density foods, increasing the availability of foods that are low in fat and low in energy density. Foods that are naturally low in fat and energy density, such as fruits, vegetables, and whole grains, should be made easily available and affordable in both restaurants and grocery stores [18]. Many lifestyle habits begin during childhood thus, parents and families should encourage their children to make healthy choice [19]. Schools should encourage children to engage in daily physical activity [20]. Other choices may include using weight loss medications (Reductil 10 $\mathrm{mg}$, Orlistat $120 \mathrm{mg}$ ) and weight loss surgery [21].

\section{Aim}

This study was conducted to investigate the eating habits in a sample of overweight and obese Iraqi subjects who attend Al-Kindy obesity therapy and research unit.

\section{Methods}

\section{Design, sample and data collection}

This study was approved by scientific and ethical committee of Alkindy College of Medicine; a cross-sectional study was carried out on overweight and obese patients who attend the obesity unit in Al-Kindy Collage of Medicine in Baghdad, Iraq. The study was conducted from February to May 2016. After taking an informed consent from each participant, a total of 113 obese subject were asked to participate and fill out a questionnaire related to their eating, drinking and smoking habits and a total of 111 agreed to participate and they completed the questionnaire with our assistance. Filling each questionnaire took about 10 minutes and items asked were skipping a meal, tendency of eating (alone or in front of TV, late night snacks, fatty food, salty food, sweets, fruits, fast food), daily water intake and nutritional balance. Body mass index (BMI) was used to assess subjects' weight status. According to guidelines stated by the National Institutes of Health, weight status was classified into four categories: overweight (25-29.9), obese class 1 (30-34.9), obese class 2 (35-39.9) and obese class $3(\geq 40)$.

\section{Data analysis}

Statistical analyses were performed using the Statistical Package for Social Sciences (version 17.0, SPSS, Inc) software. To summarize the data, we constructed cross-tabulation tables, and then used chisquare test to determine association between eating behaviors and BMI class. All reported P values were made on the basis of 2-sided tests and compared to a significance level of $5 \%$; differences were considered statistically significant at $\mathrm{P}<0.05$.

\section{Results}

In our cross sectional study the total number of participants was 111 with 73 Females (65.8\%) and 38 males (34.2\%). The mean age of the participants was $39.69 \pm 12.240$ years. All of the subjects completed the questionnaire with our assistance. Table 1 summarizes the characteristics of subjects.

Table 1: Characteristics of subjects $(n=111)$.

\begin{tabular}{|c|c|c|c|c|c|c|}
\hline Variable & OB1\% & OB2\% & OB3\% & OW\% & Total\% & P-value \\
\hline \multicolumn{7}{|l|}{ Marital state (\%) } \\
\hline Married & $38.6 \%$ & $26.1 \%$ & $26.1 \%$ & $9.1 \%$ & $79.3 \%$ & 0.008 \\
\hline Single & $65.2 \%$ & $17.4 \%$ & $8.7 \%$ & $8.7 \%$ & $20.7 \%$ & \\
\hline \multicolumn{7}{|l|}{ Gender (\%) } \\
\hline Female & $39.7 \%$ & $27.4 \%$ & $26.0 \%$ & $6.8 \%$ & $65.8 \%$ & 0.044 \\
\hline Male & $52.6 \%$ & $18.4 \%$ & $15.8 \%$ & $13.2 \%$ & $34.2 \%$ & \\
\hline Smoker (\%) & $42.9 \%$ & $14.3 \%$ & $19.0 \%$ & $23.8 \%$ & $18.9 \%$ & 0.002 \\
\hline Drinker (\%) & $0.0 \%$ & $0.0 \%$ & $100.0 \%$ & $0.0 \%$ & $0.9 \%$ & 0.110 \\
\hline \multicolumn{7}{|l|}{ (Alcohol) } \\
\hline Family History of Obesity (\%) & $39.7 \%$ & $29.4 \%$ & $23.5 \%$ & $7.4 \%$ & $61.3 \%$ & 0.089 \\
\hline \multicolumn{7}{|l|}{ Age (\%) } \\
\hline$\leq 18$ years & $50.0 \%$ & $33.3 \%$ & $16.7 \%$ & $0.0 \%$ & $5.4 \%$ & 0.204 \\
\hline $19-60$ years & $44.1 \%$ & $24.5 \%$ & $22.5 \%$ & $8.8 \%$ & $91.9 \%$ & \\
\hline$>60$ years & $33.3 \%$ & $0.0 \%$ & $33.3 \%$ & $33.3 \%$ & $2.7 \%$ & \\
\hline Anti-Obesity Drugs (\%) & $33.3 \%$ & $22.2 \%$ & $38.9 \%$ & $5.6 \%$ & $16.2 \%$ & 0.075 \\
\hline Count calories (\%) & $54.5 \%$ & $27.3 \%$ & $18.2 \%$ & $0.0 \%$ & $9.9 \%$ & 0.169 \\
\hline \multicolumn{7}{|l|}{ DM (\%) /HT } \\
\hline DM & $25.0 \%$ & $50.0 \%$ & $25.0 \%$ & $0.0 \%$ & $3.6 \%$ & 0.048 \\
\hline $\mathrm{DM} / \mathrm{HT}$ & $23.1 \%$ & $30.8 \%$ & $38.5 \%$ & $7.7 \%$ & $11.7 \%$ & \\
\hline HT & $45.5 \%$ & $13.6 \%$ & $31.8 \%$ & $9.1 \%$ & $19.8 \%$ & \\
\hline NON & $48.6 \%$ & $25.0 \%$ & $16.7 \%$ & $9.7 \%$ & $64.9 \%$ & \\
\hline \multicolumn{7}{|l|}{ Occupation (\%) } \\
\hline Employee & $53.1 \%$ & $32.7 \%$ & $30.6 \%$ & $55.0 \%$ & $43.2 \%$ & 0.014 \\
\hline No Job & $46.9 \%$ & $67.3 \%$ & $69.4 \%$ & $45.0 \%$ & $56.8 \%$ & \\
\hline
\end{tabular}

Results represent percent of total; OB1 = obesity grade-1; OB2 = obesity grade-2; OB3 = obesity grade-3; OW = over weight, DM = diabetes mellitus; HT = hypertension. $P$-value $\leq 0.05$ considered being significant; $P$-value $\leq 0.001$ considered being highly significant. 
Table 2: Subjects response to questions related to their meals.

\begin{tabular}{|c|c|c|c|c|c|c|c|c|}
\hline \multirow[b]{2}{*}{ Questions } & \multirow[b]{2}{*}{ Levels } & \multirow[b]{2}{*}{ Total $\mathbf{N}=$} & \multirow[b]{2}{*}{$\%$} & \multicolumn{2}{|c|}{ Male } & \multicolumn{2}{|c|}{ Female } & \multirow[t]{2}{*}{ P-value } \\
\hline & & & & $N=$ & $\%$ & $\mathbf{N}=$ & $\%$ & \\
\hline \multirow[t]{5}{*}{ Number of meals/day } & 2 & 31 & 27.9 & 11 & 28.9 & 20 & 27.4 & 0.000 \\
\hline & 3 & 61 & 55.0 & 21 & 55.3 & 40 & 54.8 & \\
\hline & 4 & 11 & 9.9 & 3 & 7.9 & 8 & 11.0 & \\
\hline & 5 & 7 & 6.3 & 3 & 7.9 & 4 & 5.5 & \\
\hline & More than 5 & 1 & 9 & 0 & 0 & 1 & 1.4 & \\
\hline \multirow[t]{2}{*}{ Mid meal snacks } & Yes & 72 & 67.9 & 24 & 63.2 & 48 & 65.8 & 0.186 \\
\hline & no & 39 & 35.1 & 14 & 36.8 & 25 & 34.2 & \\
\hline \multirow[t]{3}{*}{ Fatty food (fried) } & Always & 70 & 63.1 & 21 & 55.3 & 49 & 67.1 & 0.015 \\
\hline & Sometimes & 26 & 23.4 & 11 & 28.9 & 15 & 20.5 & \\
\hline & Rarely & 15 & 13.5 & 6 & 15.8 & 9 & 12.3 & \\
\hline \multirow[t]{3}{*}{ Fruits and vegetables } & Always & 70 & 63.1 & 25 & 65.8 & 45 & 61.6 & 0.237 \\
\hline & Sometimes & 32 & 28.8 & 9 & 23.7 & 23 & 31.5 & \\
\hline & rarely & 9 & 8.1 & 4 & 10.5 & 5 & 6.8 & \\
\hline \multirow[t]{3}{*}{ Sweets and chocolate } & Always & 59 & 53.2 & 16 & 42.1 & 43 & 58.9 & 0.722 \\
\hline & Sometimes & 26 & 23.4 & 12 & 31.6 & 14 & 19.2 & \\
\hline & rarely & 26 & 23.4 & 10 & 26.3 & 16 & 21.9 & \\
\hline \multirow[t]{3}{*}{ Skipping breakfast } & Always & 40 & 36.0 & 16 & 42.1 & 24 & 32.9 & 0.065 \\
\hline & Sometimes & 19 & 17.1 & 6 & 15.8 & 13 & 17.8 & \\
\hline & rarely & 52 & 46.8 & 16 & 42.1 & 36 & 49.3 & \\
\hline \multirow[t]{3}{*}{ Food is mainly } & Home made & 84 & 75.7 & 27 & 71.1 & 57 & 78.1 & 0.402 \\
\hline & Fast food & 21 & 18.9 & 8 & 21.1 & 13 & 17.8 & \\
\hline & both & 6 & 5.4 & 3 & 7.9 & 3 & 4.1 & \\
\hline
\end{tabular}

Results represent percent of total; P-value $\leq 0.05$ considered being significant; P-value $\leq 0.001$ considered being highly significant.

Class 1 obesity was more common in single subjects (65.2\%) compared to married subjects $(58.6 \%)$ but overweight was more common in married subjects $(9.1 \%)$ compared to single subjects $(8.7 \%)$. Obesity class 1 and overweight was more common in males (52.6\% and $13.2 \%$ respectively) compared to females $(39.7 \%$ and $6.8 \%$ respectively) also it was more common among smokers (42.9\%) and subjects with history of family obesity (39.7\%). Obesity class 1 was most common in subjects $\leq 18$ years old $(50 \%)$ and $19-60$ years old (44.1\%), while obesity class 1 and class 3 are equally prevalent in subjects $>60$ years old, in contrast to it, overweight was found highest in subjects $>60$ year old $(33.3 \%)$, less in subjects $19-60(8.8 \%)$ and least one in subjects $\leq 18(0 \%)$.

Obesity class 3 was more common in subjects who use Antiobesity drugs (38.9\%) while the overweight was found in $(5.6 \%)$ of them. In subjects who tend to count calories, Obesity class 1 was the most common (54.5\%). Obesity class 1 was highest in subjects who don't complain from hypertension (HT) or diabetes mellitus (DM) (48.6\%) and also high in subjects with HT only (45.5\%). In subjects with DM, obesity class 2 was more common (50\%) while Obesity class 3 was more common in subjects with both HT and DM (38.5\%). Meanwhile the overweight prevalence was highest in subjects without HT or DM (9.7\%), less in HT, HT and DM, in DM (9.1\%, 7.7\%, 0\%) respectively.

Table 2 Summarizes the subject's response to questions related to their meals, eating habits of the subjects were compared by gender. Regarding the number of meals per day, the majority of subjects (55\%) reported having 3 meals per day (54.8\% of females as compared to $55.3 \%$ of males). (65.8\%) females reported eating mid meal snacks compared to $(63.2 \%)$ males. Males tend to eat more fruits and vegetables daily compared to females $(65.8 \%$ vs. $61.6 \%$ respectively) while females tend to eat more fatty food daily as compared to males (67.1\% vs. $55.3 \%$ respectively), also chocolate and sweets intake was more common in female subjects (58.9\%) as compared to male subjects $(42.1 \%)$. Female subjects showed healthier eating habits compared to male subjects in terms of breakfast intake; $(49.3 \%)$ of the total females reported rarely skipping breakfast compared to (42.1\%) males. $(78.1 \%)$ Females and $(71.1 \%)$ males reported that their food was mainly homemade.
Table 3 indicates the response of subjects to questions based of lifestyle practices. The majority of the subjects (45\%) tend to eat until feeling uncomfortable (males $47.4 \%$ compared to $43.8 \%$ females). A total of (36\%) of subjects rarely eat when they are not hungry with no gender difference ( $36.8 \%$ males vs. $35.6 \%$ females). The majority of the subjects (37.8\%) reported eating outside their homes once weekly (31.6\% males vs. $41.6 \%$ females). A total of (45.9\%) of subjects rarely eat right before going to sleep (44.7\%) males compared with (46.6\%) females. The intake of salt and sweets (44.1\%); (males $44.7 \%$ vs. $43.8 \%$ females). A total of (43.2\%) of participants reported daily intake of water more than 4 cups with significant gender differences $(57.9 \%$ males vs. $35.6 \%$ females). The majority of subjects (56.8\%) eat while watching TV, (65.8\% males vs. $52.1 \%$ females). A total of $(53.2 \%)$ tend to eat more when they have negative emotions (males $34.2 \%$ vs. $63 \%$ females).

\section{Discussion}

The purpose of the study was to assess the association of overweight and obesity with eating habits in a sample of 111 participants. Body mass index was used to assess weight status. We found a positive association between gender and obesity $(\mathrm{p}$-value $=0.044)$ in which obesity was more common among Females than Males. A total of $(61.2 \%)$ of females were obese compared to $(29.7 \%)$ of males. Moreover, obese peoples had higher values of percentage body fat. The higher rate of obesity among females is expected since most of females are housewives (75.34\%), that is similar to the findings in a study performed in Turkey which reported that prevalence of obesity in adults (n 24,788; 13,708 women and 11,080 men) in Turkey was $22.3 \%$ and the prevalence rate in women $(29.9 \%)$ was higher than in men $(12.9 \%)(\mathrm{P}$-Value $=0.001)$ [22]. But a study conducted among 220 students at the Lebanese American University [23] shows that the prevalence rate of obesity was $12.5 \%$ in males compared to $3.2 \%$ in females [24] which was similar to the findings in a research conducted among 749 students (68\% females and $32 \%$ males) recruited from the State University of the Basque Country, prevalence rate of overweight and obesity was $25 \%$ in males compared to $13.9 \%$ in females [25]; another study conducted in the University of Kuwait among 842 students reported a high prevalence rate of overweight and obesity 
Table 3: Summary of questions related to their lifestyle practices.

\begin{tabular}{|c|c|c|c|c|c|c|c|c|}
\hline \multirow[b]{2}{*}{ Questions } & \multirow[b]{2}{*}{ level } & \multirow[b]{2}{*}{ Total $\mathbf{N}=$} & \multirow[b]{2}{*}{$\%$} & \multicolumn{2}{|c|}{ Male } & \multicolumn{2}{|c|}{ Female } & \multirow[b]{2}{*}{$P$ value } \\
\hline & & & & $\mathbf{N}=$ & $\%=$ & $\mathbf{N}=$ & $\%=$ & \\
\hline $\begin{array}{l}\text { Eating until feeling uncomfortably } \\
\text { full }\end{array}$ & $\begin{array}{l}\text { Always } \\
\text { sometimes } \\
\text { rarely }\end{array}$ & $\begin{array}{l}50 \\
37 \\
24\end{array}$ & $\begin{array}{l}45.0 \\
33.3 \\
21.6\end{array}$ & $\begin{array}{l}18 \\
13 \\
7\end{array}$ & $\begin{array}{l}47.4 \\
34.2 \\
18.4\end{array}$ & $\begin{array}{l}32 \\
24 \\
17\end{array}$ & $\begin{array}{l}43.8 \\
32.9 \\
23.3\end{array}$ & 0.675 \\
\hline Eating while not hungry & $\begin{array}{l}\text { Always } \\
\text { sometimes } \\
\text { rarely }\end{array}$ & $\begin{array}{l}34 \\
37 \\
40\end{array}$ & $\begin{array}{l}30.6 \\
33.3 \\
36.0\end{array}$ & $\begin{array}{l}11 \\
13 \\
14\end{array}$ & $\begin{array}{l}28.9 \\
34.2 \\
36.8\end{array}$ & $\begin{array}{l}23 \\
24 \\
26\end{array}$ & $\begin{array}{l}31.5 \\
32.9 \\
35.6\end{array}$ & 0.083 \\
\hline Times you eat outside & $\begin{array}{l}0 \\
1 \\
2 \\
\text { More than } 2\end{array}$ & $\begin{array}{l}28 \\
42 \\
16 \\
25\end{array}$ & $\begin{array}{l}25.2 \\
37.8 \\
14.4 \\
22.5\end{array}$ & $\begin{array}{l}7 \\
12 \\
7 \\
12\end{array}$ & $\begin{array}{l}18.4 \\
31.6 \\
18.4 \\
31.6\end{array}$ & $\begin{array}{l}21 \\
30 \\
9 \\
13\end{array}$ & $\begin{array}{l}28.8 \\
41.1 \\
12.3 \\
17.8\end{array}$ & 0.020 \\
\hline Eating right before going to sleep & $\begin{array}{l}\text { Always } \\
\text { Sometimes } \\
\text { rarely }\end{array}$ & $\begin{array}{l}29 \\
31 \\
51\end{array}$ & $\begin{array}{l}26.1 \\
27.9 \\
45.9\end{array}$ & $\begin{array}{l}11 \\
10 \\
17\end{array}$ & $\begin{array}{l}28.9 \\
26.3 \\
44.7\end{array}$ & $\begin{array}{l}18 \\
21 \\
34\end{array}$ & $\begin{array}{l}24.7 \\
28.8 \\
46.6\end{array}$ & 0.363 \\
\hline I prefer & $\begin{array}{l}\text { Both } \\
\text { Non } \\
\text { Salty } \\
\text { sweets }\end{array}$ & $\begin{array}{l}49 \\
3 \\
30 \\
29\end{array}$ & $\begin{array}{l}44.1 \\
2.7 \\
27.0 \\
26.1\end{array}$ & $\begin{array}{l}17 \\
0 \\
15 \\
6\end{array}$ & $\begin{array}{l}44.7 \\
0 \\
39.5 \\
15.8 \\
\end{array}$ & $\begin{array}{l}32 \\
3 \\
15 \\
23\end{array}$ & $\begin{array}{l}43.8 \\
4.1 \\
20.5 \\
31.5\end{array}$ & 0.012 \\
\hline Cups of water /day & $\begin{array}{l}1 \\
2 \\
3 \\
4 \\
\text { More than } 4\end{array}$ & $\begin{array}{l}15 \\
11 \\
20 \\
17 \\
48\end{array}$ & $\begin{array}{l}13.5 \\
9.9 \\
18.0 \\
15.3 \\
43.2\end{array}$ & $\begin{array}{l}3 \\
4 \\
6 \\
3 \\
22\end{array}$ & $\begin{array}{l}7.9 \\
10.5 \\
15.8 \\
7.9 \\
57.9\end{array}$ & $\begin{array}{l}12 \\
7 \\
14 \\
14 \\
26\end{array}$ & $\begin{array}{l}16.4 \\
9.6 \\
19.2 \\
19.2 \\
35.6\end{array}$ & 0.000 \\
\hline Eating while watching TV & $\begin{array}{l}\text { Yes } \\
\text { No }\end{array}$ & $\begin{array}{l}63 \\
48\end{array}$ & $\begin{array}{l}56.8 \\
43.2\end{array}$ & $\begin{array}{l}25 \\
13\end{array}$ & $\begin{array}{l}65.8 \\
34.2\end{array}$ & $\begin{array}{l}38 \\
35\end{array}$ & $\begin{array}{l}52.1 \\
47.9\end{array}$ & 0.932 \\
\hline $\begin{array}{l}\text { Increased food intake with negative } \\
\text { emotions }\end{array}$ & $\begin{array}{l}\text { Yes } \\
\text { No }\end{array}$ & $\begin{array}{l}59 \\
52\end{array}$ & $\begin{array}{l}53.2 \\
46.8\end{array}$ & $\begin{array}{l}13 \\
25\end{array}$ & $\begin{array}{l}34.2 \\
65.8\end{array}$ & $\begin{array}{l}46 \\
27\end{array}$ & $\begin{array}{l}63.0 \\
37.0\end{array}$ & 0.744 \\
\hline
\end{tabular}

Results represent percent of total; P-value $\leq 0.05$ considered being significant; $P$-value $\leq 0.001$ considered being highly significant.

$32 \%, 8.9 \%$, respectively in male more than in female [26]. In our study we found a positive association between number of meals per day and incidence of obesity (p-value 0.000) 55.0\% (55.3\% Males and 54.8\% Females) of the subjects eat three meals per day in comparison with previous study [23], in which $52.7 \%$ (47.9\% males and 56.5\% females) of the students eat two meals per day. In a study conducted in India it was found that $0.8 \%$ of participants who had the habit of having snacks at midnight were obese with a p-value of 0.0015 while in our study we did not find any association between mid meal snacking and the prevalence obesity and overweight although the percentage of subjects who eat mid meals snacks was $67.9 \%$. The present study clearly showed that eating food rich with fat has a positive association $(\mathrm{p}$ - value $=0.015)$ with obesity (in which percentage of people who always eat fatty food is $63.1 \%)$, (55.3\% Males and $67.1 \%$ Females). A similar findings have been reported in a northeastern Japan study $(\mathrm{n}=290) 19 \%$ [27]. In our study we found that eating fast food has a positive association with obesity $(\mathrm{p}$-value $=0.020)$ that is similar to the findings of a research conducted by the Lebanese American University [24]. One study showed that watching TV for long periods was associated with lower level of HDL cholesterol and higher levels of leptin [28]. According to nurses' health study, watching TV for $>2$ hours per day was associated with $23 \%$ increase obesity in adult women [29]. Also Eating while watching TV according to Seoul study in South Korea [30], with a sample of $(\mathrm{n}=232)$ has a great association ( $p$-value $=0.07$ ) with being obese. However, In our study we found that eating while watching TV (56.8\%, 65.8\% Males and 52.1\% Females) $(\mathrm{p}$-value $=0.932)$ and eating until full $(45.0 \%, 47.4 \%$ Males and $43.8 \%$ Females) ( $p$-value $=0.675)$ have no significant association with being obese; but in a Japanese research sample of $(n=290)$, eating until full showed significant association [31,32]. As expected the alcohol intake is not common in our society just 1 subject from a sample of 111, which is similar to the research conducted in Lebanon due to religions and the practice of faith. However, in a study conducted in
Canada [33] stated that light to moderate alcohol intake is less likely to be a risk factor for obesity than heavy and binge drinking that have been more consistently linked with adiposity. In a U.S.A study it was observed that becoming married was associated with an average BMI increase [34-36]. The present results in our study shows that marriage $(79.27 \%)$ is also associated $(\mathrm{p}$-value $=0.008)$ with increase BMI than being single (20.72\%). Studies have indicated that drinking water may induce thermo genesis and increase metabolic rate [37]. Thus increasing energy expenditure. However, this finding was not observed in other studies [38]. It has also been hypothesized that liquid volume can increase gastric distension and satiety compared with not drinking any fluids, thus reducing energy intake at the subsequent meal, that is similar to our study findings which refers that water intake has a positive association with being obese.

We also found a positive association between obesity and the intake of salts and sweets ( $p$-value $=0.012$ ) in our study that is similar to a study in UK which suggest there may be a direct link between salt intake and obesity, this has been highlighted in a nationally representative sample of the UK population, with a $1 \mathrm{~g} /$ day increase in salt intake being associated with an increased risk of being overweight or obese by $28 \%$ in children and $26 \%$ in adults [36]. Regarding sugar intake, the rising prevalence of obesity in children has been linked in part to the consumption of sugar-sweetened drinks [39]. An association between occupation and employment situation and obesity was observed ( $\mathrm{p}$-value $=0.014)$ in our study $(75.342 \%$ females have no job). Women engaged in domestic duties were more often obese than employed women (19.178\% females have job and $5.479 \%$ females student). Performing domestic duties without fixed hours or remuneration, and having a constant access to food, may have contributed to obesity in these women. These results are concordant with the results of studies [22,28]. Being obese increases the risk of various weight related diseases including type $2 \mathrm{DM}$ because excess fat appears to disrupt various metabolic functions, heavily influencing 
the cascade of events that promotes insulin resistance, according to the study that is published in the diabetes journal [40] and our study has found a positive association ( $p$-value $=0.048$ ) between diabetes mellitus / hypertension and the prevalence of obesity and overweight.

Our study showed no significant association between eating the fruits, colored vegetables with obesity that similar to Lebanese American University study [23]. Furthermore, results obtained in this study showed that there's no significant association between obesity and skipping breakfast; in contrast to a USA study that found a significant association between skipping breakfast and increased risk of obesity that is related to increase in the proportion of either breakfast or dinner. However, the temporal distribution of eating events across the day was not related to obesity. Also there are reports suggesting that individuals who do not eat breakfast have a greater overall daily energy intake [41,42]. Study using data from the National Weight Control Registry suggests that eating breakfast is essential for a successful weight loss process. Individuals who do not eat early in the day may tend to be hungry later on and then may consume a greater number of calories during the evening hours than individuals who eat consistently throughout the day [43]. Greater energy intake may result in greater fat storage and, thus, it may be one of the factors that lead to an increase in body weight [44].

About (41.4\% OB, 5.4\% OW)\% of our subjects are rarely skipping breakfast. Another study showed that the obese subjects who don't skip breakfast would be more active but they don't loss their weight as reported in University of Bath study [45]. We found a significant association between eating outside in restaurants and obesity that is similar to USA Department of Agriculture's 1995 Continuing Survey of Food Intakes by Individuals suggest that food obtained away from home is generally higher in fat, saturated fat, and cholesterol than food prepared at home due to eating patterns and obesity in a freeliving US adult population study [46].

The present study indicated that smoking has a positive association ( $\mathrm{p}$-value $=0.002$ ) with being obese (in which obese percentage was higher in non-smokers subjects $76.6 \%$ ). A similar results found in a study on twin pairs that reported that the smoker subjects were an average of 3.2,2.4, and $4.0 \mathrm{~kg}$ lighter, respectively, than nonsmokers [47]; but other studies have different outcomes in that smoking rates were higher among obese participants than among overweight and non-obese participants (34.9\%, 37.1\%, 43.6\% for non-obese, overweight and obese, respectively; $\mathrm{P}<0.001$ ) [48]. Even if there was no significant association between family history of obesity and being obese in our results however a study conducted in Gambia in Africa reported those with a family history of obesity had a higher BMI and were at increased risk of obesity [49]. We found that there is no association between BMI and eating while not hungry $\mathrm{p}=$ 0.083 . While in a study conducted in Greece showed that there was a great association $\mathrm{p}=0.0001$ [50]. A study performed in USA reported that there was no association between being obese or overweight and eating right before sleep $(\mathrm{p}=0.85)$ [44]. These results are similar to our findings.

\section{Conclusion}

We found statistically significant positive association between specific eating behaviors, namely: number of meals per day, eating fatty food and fast food with obesity and overweight; employment of nutrition and health promotion program, weight-control strategies that developed early in life are highly recommended to reduce the incidence of obesity and overweight in a sample of Iraqi subjects.

\section{Limitations}

The present study has several limitations firstly; the findings of this study was limited by the use of a sample of people from just one obesity center which may not be a representative of all Iraqis, furthermore the people who are overweight rarely visits the obesity center thus the sample size of overweight subjects is very small compared to obese subjects. Second, the number of females is more than the males. Third, we used self reports to gather data on factors related to lifestyle, which may have influenced the validity of the results.

\section{Acknowledgments}

Thanks to all the dedicated participants who worked hard to complete this study.

\section{References}

1. (2000) Obesity: preventing and managing the global epidemic. Report of a WHO consultation. World Health Organ Tech Rep Ser 894: 1-253.

2. World health organization obesity and overweight.

3. Weight control information network understanding adult obesity 2004.

4. Swidan A (1997) Nutritional assessment of females 10-60 years old. house hold survey, Baghdad, general federation of Iraqi women.

5. (2003) Diet, nutrition and the prevention of chronic diseases. World Health Organ Tech Rep Ser 916: 1-149.

6. World Cancer Research Fund / American Institute for Cancer Research (2007) Food, Nutrition, Physical Activity, and the Prevention of Cancer: a Global Perspective. Washington DC

7. Zandian M, loakimidis I, Bergh C, Brodin U, Södersten P (2009) Decelerated and linear eaters: effect of eating rate on food intake and satiety. Physiol Behav 96: 270-275

8. Whitney E, Rolfes RS. Understanding Nutrition. Belmont: Thomson Higher Education 2007.

9. Reilly JJ, Armstrong J, Dorosty AR, Emmett PM, Ness A, et al. (2005) Early life risk factors for obesity in childhood: cohort study. BMJ 330: 1357

10. Newby PK (2007) Are dietary intakes and eating behaviors related to childhood obesity? A comprehensive review of the evidence. J Law Med Ethics 35: 35-60.

11. http://www.livestrong.com/article/339349-why-did-obesity-increase-somuch-in-america/.

12. Wardle J, Gibson EL (2002) Impact of stress on diet: processes and implications. In: Stansfeld SA, Marmot M, Stress and the Heart. BMJ Books London 124-149.

13. De Vriendt, Moreno LA, De Henauw S (2009) Chronic stress and obesity in adolescents: scientific evidence and methodological issues for epidemiological research. Nutr Metab Cardiovasc Dis 19: 511-519.

14. Lee HA, Lee WK, Kong KA, Chang N, Ha EH, et al. (2011) The effect of eating behavior on being overweight or obese during preadolescence. J Prev Med Public Health 44: 226-233.

15. Frier BM, Truswell AS, Shepherd J, Looy A, Jung R (1999) Diabetes mellitus, and nutritional and metabolic disorders. In: Haslett $C$, Chilvers ER, Hunter JA, Boon NA, Davidson's principles and practice of medicine. (18 $\left.8^{\text {th }} \mathrm{edn}\right)$, Edinburgh UK, Churchill Livingstone 471-509.

16. Ottova V, Erhart M, Rajmil L, Dettenborn-Betz L, Ravens-Sieberer U (2012) Overweight and its impact on the health-related quality of life in children and adolescents: results from the European KIDSCREEN survey. Qual Life Res 21: $59-69$.

17. Müller-Riemenschneider F, Reinhold T, Berghöfer A, Willich SN (2008) Health-economic burden of obesity in Europe. Eur J Epidemiol 23: 499-509.

18. Hill JO, Peters JC (1998) Environmental contributions to the obesity epidemic. Science 280: 1371-1374.

19. http://www.nhlbi.nih.gov/health/health-topics/topics/obe/prevention.

20. Birch LL, Johnson SL, Andresen G, Peters JC, Schulte MC (1991) The variability of young children's energy intake. N Engl J Med 324: 232-235.

21. http://www.mayoclinic.org/diseases-conditions/obesity/basics/treatment/con$200148342016 / 03 / 28$.

22. Satman I, Yilmaz MT, Sengul AM, Salman S, Uygur S, et al. (1999) Prevalence of obesity in Turkey: 22nd Congress of Endocrinology of Metabolic Diseases of Turkey and Postgraduate Training Courses. Turkish J Endocrinol Metab 3: 67 .

23. Yahia N, Achkar A, Abdallah A, Rizk S (2008) Eating habits and obesity among Lebanese university students. Nutr J 7: 32.

24. Field AE, Cheung L, Wolf AM, Herzog DB, Gortmaker SL, et al. (1999) Exposure to the mass media and weight concerns among girls. Pediatrics 103: E36.

25. Arroyo Izaga M, Rocandio Pablo AM, Ansotegui Alday L, Pascual Apalauza E, Salces Beti I, et al. (2006) Diet quality, overweight and obesity in university students. Nutr Hosp 21: 673-679.

26. al-Isa AN (1999) Obesity among Kuwait University students: an explorative study. J R Soc Promot Health 119: 223-227. 
27. Kimura Y, Nanri A, Matsushita Y, Sasaki S, Mizoue T (2011) Eating behavior in relation to prevalence of overweight among Japanese men. Asia Pac J Clin Nutr 20: 29-34

28. Hu FB (2003) Sedentary lifestyle and risk of obesity and type 2 diabetes. Lipids 38: 103-108.

29. Hu FB, Li TY, Colditz GA, Willett WC, Manson JE (2003) Television watching and other sedentary behaviors in relation to risk of obesity and type 2 diabetes mellitus in women. JAMA 289: 1785-1791.

30. Lee HA, Lee WK, Kong KA, Chang N, Ha EH, et al. (2011) The effect of eating behavior on being overweight or obese during preadolescence. J Prev Med Public Health 44: 226-233.

31. Yamasaki T (1995) Relation of life style, working posture and job category to body mass index change in young male workers. Nihon Koshu Eisei Zassh 42: $1042-1053$

32. Maruyama K, Sato S, Ohira T, Maeda K, Noda H, et al. (2008) The joint impact on being overweight of self reported behaviours of eating quickly and eating until full: cross sectional survey. BMJ 337: a2002.

33. Traversy G, Chaput JP (2015) Alcohol Consumption and Obesity: An Update. Curr Obes Rep 4: 122-130.

34. Rauschenbach B, Sobal J, Frongillo EA Jr (1995) The influence of change in marital status on weight change over one year. Obes Res 3: 319-327.

35. Jeffery RW, Rick AM (2002) Cross-sectional and longitudinal associations between body mass index and marriage-related factors. Obes Res 10: 809815 .

36. High Salt Intake May Directly Increase Risk of Obesity New Study Shows.

37. Boschmann M, Steiniger J, Hille U, Tank J, Adams F, et al. (2003) Waterinduced thermogenesis. J Clin Endocrinol Metab 88: 6015-6019.

38. Brown CM, Dulloo AG, Montani JP (2006) Water-induced thermogenesis reconsidered : the effects of osmolality and water temperature on energy expenditure after drinking. J Clin Endocinol Metab 91: 3598-3602.

39. Ludwig DS, Peterson KE, Gortmaker SL (2001) Relation between consumption of sugar-sweetened drinks and childhood obesity: a prospective, observational analysis. Lancet 357: 505-508.

40. How Obesity Is Related to Diabetes.

41. Stanton JL Jr, Keast DR (1989) Serum cholesterol, fat intake, and breakfast consumption in the United States adult population. J Am Coll Nutr 8: 567-572.

42. Morgan KJ, Zabik ME, Stampley GL (1986) The role of breakfast in diet adequacy of the U.S. adult population. J Am Coll Nutr 5: 551-563.

43. Hunt S, Groff J (1990) Advanced nutrition and human metabolism. St. Paul, MN, West Publishing Company.

44. Ma Y, Bertone ER, Stanek EJ 3rd, Reed GW, Hebert JR, et al. (2003) Association between eating patterns and obesity in a free-living US adult population. Am J Epidemiol 158: 85-92.

45. http://www.bath.ac.uk/news/2016/02/13/science-eating-breakfast/.

46. Lin BH, Guthrie J, Frazao E (1999) Away-from-home foods increasingly important to quality of American diet. Washington, DC: Economic Research Service, US Department of Agriculture.

47. Eisen SA, Lyons MJ, Goldberg J, True WR (1993) The impact of cigarette and alcohol consumption on weight and obesity. An analysis of 1911 monozygotic male twin pairs. Arch Intern Med 153: 2457-2463.

48. Zimlichman E, Kochba I, Mimouni FB, Shochat T, Grotto I, et al. (2005) Smoking habits and obesity in young adults. Addiction 100: 1021-1025.

49. van der Sande MA, Walraven GE, Milligan PJ, Banya WA, Ceesay SM, et al. (2001) Family history: an opportunity for early interventions and improved control of hypertension, obesity and diabetes. Bull World Health Organ 79: 321-328.

50. Patsopoulou A, Tsimtsiou Z, Katsioulis A, Rachiotis G, Malissiova E, et al. (2015) Prevalence and Risk Factors of Overweight and Obesity among Adolescents and Their Parents in Central Greece (FETA Project). Int J Environ Res Public Health 13: 83. 